\title{
Histone-Arginine Methyltransferase CARM1
}

National Cancer Institute

\section{Source}

National Cancer Institute. Histone-Arginine Methyltransferase CARM1. NCI Thesaurus.

Code C88223.

Histone-arginine methyltransferase CARM1 (585 aa, $63 \mathrm{kDa}$ ) is encoded by the human CARM1 gene. This protein is involved in the mediation of protein methylation that, in turn, regulates both chromatin organization and transcription. 